Bangl. J. Vet. Med. (2011). 09 (2): 137 - 143

\title{
UDDER-HALVE-WISE COMPARATIVE PREVALENCE OF CLINICAL AND SUB- CLINICAL MASTITIS IN LACTATING GOATS WITH THEIR BACTERIAL PATHOGENS AND ANTIBIOTIC SENSITIVITY PATTERNS IN BANGLADESH
}

\author{
H. Sarker and M. A. Samad* \\ Department of Medicine, Faculty of Veterinary Science, Bangladesh Agricultural University, Mymensingh- \\ 2202, Bangladesh
}

\begin{abstract}
Goats are the major parts of subsidiary economy of the rural people in Bangladesh. Dairy animals including lactating goats are prone to the intramammary infection (IMI) and associated with a lot of economic impact on the farmers but the reports on caprine mastitis are very limited in inland literature. This study was undertaken to determine the udder-halve-wise comparative prevalence of clinical and sub-clinical caprine mastitis with their associated bacterial pathogens and antibiotic sensitivity patterns during the period from January to May 2010. The teat and udder of a lactating population of 1025 Black Bengal goats maintained under rural (village) condition in two different districts (Joypurhat and Mymensingh) of Bangladesh were physically examined, of which 54 (5.27\%) goats had clinical mastitis which constituted as experimental animals for this study. Of the 54 selected goats, 59 (54.63\%) udder-halves were affected with clinical mastitis whereas the remaining 49 (45.37\%) udder-halves of the selected goats were found physically normal. Out of 59 udder-halves, 49 (90.74\%) were unilaterally and $5(9.26 \%)$ were bilaterally affected with clinical mastitis. The prevalence of clinical mastitis was found significantly $(\mathrm{p}<0.01)$ higher in left udder-haves $(\mathrm{H}=47$; 79.66\%) in comparison to the right $(\mathrm{H}=12 ; 20.34 \%)$ udder-halves. Milk samples collected from all the 108 udder-halves were examined bacteriologically, of which 102 (94.44\%) udder-halves had bacterial infection. No significant differences was observed on the status of bacterial pathogens between clinically $(\mathrm{H}=$ 55; 93.22\%) and sub-clinically ( $\mathrm{H}=47 ; 95.92 \%)$ affected udder-halves, and between the single $(\mathrm{CH}=45 ; 76.27 \%$ and SCH = $35 ; 71.43 \%)$ and mixed $(\mathrm{CH}=10 ; 16.95 \%$ and $\mathrm{SCH}=12 ; 24.49 \%)$ bacterial infections in both the clinical and sub-clinical mastitis udder-halves. The major bacterial pathogens isolated were Staphylococcus spp. which showed to be highest frequency (38.98\%), followed by Escherichia coli (27.12\%) and Bacillus spp. (10.17\%) as a single clinical IMI whereas mixed IMI were also detected in both clinically and sub-clinically affected udder-halves. Antibiotic sensitivity results showed a relatively high level of resistance to ampicillin, amoxycillin and streptomycin, whereas gentamicin and ciprofloxacin were found to be the most effective drugs. These results indicate the high prevalence of sub-clinical mastitis in apparently normal quarters of lactating goats than those had clinical mastitis in other udder-halves, and therefore, there is a need for the prudent use of antibacterial in animal health and production through bacteriological and antibiogram studies in Bangladesh.
\end{abstract}

Key words: Lactating goats, Udder-haves-wise mastitis, Bacterial pathogens, Antibiotic sensitivity

\section{INTRODUCTION}

Bangladesh possesses about 34 million goats and more than $90 \%$ of the goats of the country are Black Bengal breed and it provides 127,000 MT meat which accounts for 25\% of total red meat in Bangladesh (FAO, 2007). The goat ranks second in position in terms of meat, milk and skin production, representing about 28, 23 and $28 \%$ respectively of the total livestock in Bangladesh. The comparative beneficial effects of goat milk with human and other livestock species have been described (Haenlein, 2004) but the goat is perhaps the most misunderstood and neglected species of livestock in Bangladesh. Although goat rearing is easy, less expensive, less laborious and highly profitable business, it is being seriously hampered due to various disease problems. Mastitis is one of the most important diseases of mammals including goats worldwide including Bangladesh (Bozhilov, 1970; Samad, 2008). Mastitis is the inflammation of mammary glands with physical, chemical and microbiological changes characterized by an increase in somatic cells, especially leukocytes in the milk and by the pathological changes in the mammary tissue. Generally, mastitis occurs in two forms which includes clinical (overt) and sub-clinical (hidden). In the clinical mastitis all the five cardinal signs of udder inflammation (redness, heat, swelling, pain and loss of milk production) are present, while the sub-clinical form is bereft of any obvious manifestation of inflammation. Mastitis is recognized as the most important and costly disease of dairy animals worldwide but also posses the risk for the transmission of milk borne zoonotic diseases (Samad, 2008). The distribution, causes, importance and antibiogram patterns of mastitis pathogens isolated from lactating goats have reported from

*Corresponding e-mail address: vetmedbd@yahoo.com

Copyright (C) 2011 Bangladesh Society of Veterinary Medicine

All right reserved 1729-7893/0232/2011 


\section{H. Sarker and M. A. Samad}

different parts of world (Manser, 1986; Contreras et al., 1995; Boscos et al., 1996; Moshi et al., 1998; Ameh et al., 1993; Ameh and Tari, 2000; Ndegwa et al., 2000; Egwu et al., 1994; Bhujbal et al., 1999; DaSilva et al., 2004; Wakwoya et al., 2006; Mbilu, 2007). However, the reports on caprine mastitis are very rare from Bangladesh where Rahman (1981) reported only the clinical occurrence and Rahman and Samad (1984) isolated Staphylococcus aureus from three clinical cases of caprine mastitis. Moreover, the greatest problem in the treatment and control of mastitis is the emergence of drug resistance due to indiscriminate use of antibacterial reported elsewhere (Jha et al., 1994) which is remained unexplored in caprine mastitis in Bangladesh. This paper describes the udder-halves-wise comparative prevalence of clinical and sub-clinical mastitis in lactating Black Bengal goats with their associated bacterial pathogens and antibiotic sensitivity patterns.

\section{MATERIALS AND METHODS}

The udder-halves-wise comparative prevalence of clinical and sub-clinical mastitis with their associated bacterial pathogens and their in vitro sensitivity patterns to different antibiotics were carried out in 54 Black Bengal goats in the districts of Joypurhat $(\mathrm{n}=36)$ and Mymensingh $(\mathrm{n}=18)$ during the period from January to May 2010. Clinical mastitis was diagnosed in 54 goats from a randomly selected population of 1025 lactating rural goats on the basis of owner history, inspection and palpation of the udder and visual examination of the milk samples. Hard swollen with painful udder and visible abnormalities of milk (milk with blood, clots, flakes, watery etc.) were diagnosed as clinical mastitis.

\section{Collection of milk samples}

Udders and teats of the randomly selected 54 lactating goats (108 udder-halves) were cleaned and dried before sample collection. Each of the 59 mastitis affected teats and 49 apparently healthy teats of 54 lactating goats was disinfected with $70 \%$ ethanol before sampling. The first few streams of milk were discarded and about $10 \mathrm{ml}$ milk samples were collected in sterile universal bottles, labeled as L or R ( $\mathrm{L}$ for left halves and R for rights halves). The milk samples were transported in an icebox with ice to the laboratory for bacteriological studies.

\section{Isolation and identification of bacteria}

The media and reagents were either obtained from Hi-Media, Mumbai, India or prepared in the laboratory as per the standard procedures (Cowan and Steel, 1974; Cruickshank et al., 1975). Bacteriological examination of 108 milk samples collected from 108 quarters of 54 lactating goats, of which 59 quarters were affected with clinical mastitis was carried out by following standard procedures (Cruickshank et al., 1975; Quinn et al., 1999).

Milk samples were incubated aerobically at $37{ }^{\circ} \mathrm{C}$ for 24 hours. Then about $10 \mu \mathrm{l}$ milk from each quarter was inoculated onto blood agar, MacConkey agar and nutrient agar plates and incubated aerobically at $37^{\circ} \mathrm{C}$ for 24 to 48 hours. Each plate was then examined for growth, morphology and hemolytic characteristics. Identification of bacteria on primary culture was made on the basis of colony morphology, hemolytic characteristics, Gram-stain reaction and catalase tests. Further each culture was subjected to various biochemical tests (Kreig and Holt, 1984). Finally, the bacteria isolated were identified on the basis of their cultural, morphological and biochemical characteristics as per method of Cruickshank et al. (1975).

\section{Antibiotic susceptibility test}

Antibiotic susceptibility test was conducted on randomly selected three different bacterial pathogens (Staphylococus spp., Escherichia coli and Bacillus spp.) isolated during the study period to 10 antibiotics using the disc diffusion method (Ellner, 1978; Quinn et al., 1999). Minimal inhibition concentration values of the bacterial organisms were analyzed for antibacterial discs (Oxoid Ltd., UK) with their corresponding concentrations include: Gentamicin (GN, $30 \mu \mathrm{g}$ ), Ciprofloxacin (CIP, $5 \mu \mathrm{g}$ ), Erythromycin (ERY, $15 \mu \mathrm{g}$ ), Chloramphenicol (C, $30 \mu \mathrm{g}$ ), Ampicillin (AMP, $10 \mu \mathrm{g}$ ), Amoxycillin (AMOX, $10 \mu \mathrm{g}$ ), Enrofloxacin (ENR, 5 $\mu \mathrm{g}$ ), Oxytetracycline (OXT, $30 \mu \mathrm{g}$ ), Doxycycline (DOX, $30 \mu \mathrm{g}$ ) and Streptomycin (SM, $10 \mu \mathrm{g}$ ).

Sensitivity to antibiotic was studied on nutrient plate and the respective plate was seeded uniformly by rubbing the swab against the entire agar surface. Each antibacterial impregnated disc was applied onto the surface of the inoculated plate by using sterile forceps. The plates were incubated at $37^{\circ} \mathrm{C}$ for 48 hours. The zone of inhibition around each disc was measured and the interpretation was made as per the zone size interpretation chart provided 
Clinical and Sub-clinical goat mastitis by the disc manufacturer. The results of sensitivity test was expressed as $3+, 2+, 1+$ and $\mathrm{R}$ expressing high, moderate, sensitive and resistant, level of susceptibility respectively.

\section{RESULTS AND DISCUSSION}

A cross-sectional study was carried out on mastitis in 108 udder-halves of 54 Black Bengal lactating goats to determine the halves-wise prevalence of clinical and sub-clinical mastitis associated bacterial pathogens and their antibiotic sensitivity patterns in Bangladesh. Each udder of 1025 lactating Black Bengal goats were examined physically in two different districts of Bangladesh, of which only 54 (5.27\%) goats were diagnosed as clinical mastitis that constitute the experimental animals for this study. Physical examination of 108 udder-halves of the 54 lactating goats showed 59 (54.63\%) udder-halves affected with clinical mastitis (Table 1). Of the 59 affected udder-halves, 49 (90.74\%) had unilateral and 5 (9.26\%) goats had bilateral clinical mastitis. Significantly (p < 0.01) higher prevalence of clinical mastitis was recorded in left udder-halves ( $n=44 ; 40.74 \%)$ in comparison to right udder-halves ( $\mathrm{n}=11 ; 1019 \%)$ in Black Bengal goats. These results could not be compared due to lack of similar reports in goats in the available literature. However, these findings support the report of Khan and Muhammad (2005) who reported highest prevalence of clinical mastitis in the left hind-quarter in buffaloes.

Table 1. Udder-halve-wise frequency of distribution of bacteria isolated from clinical and sub-clinical mastitis of Black Bengal goats

\begin{tabular}{|c|c|c|c|c|c|c|c|c|}
\hline \multirow[t]{3}{*}{$\mathrm{S} / \mathrm{N}$} & \multirow[t]{3}{*}{$\begin{array}{l}\text { Bacterial } \\
\text { isolates }\end{array}$} & \multicolumn{2}{|c|}{$\begin{array}{l}\text { Joypurhat district } \\
(\mathrm{n}=36 ; \mathrm{H}=72)\end{array}$} & \multicolumn{2}{|c|}{$\begin{array}{l}\text { Mymensingh district } \\
(\mathrm{n}=18 ; \mathrm{H}=36)\end{array}$} & \multicolumn{2}{|c|}{$\begin{array}{l}\text { Total } \\
(\mathrm{n}=54 ; \mathrm{H}=108)\end{array}$} & \multirow{3}{*}{$\begin{array}{l}\text { Overall } \\
(\mathrm{CH}=59 / \\
\mathrm{SCH}=49) \\
\text { No. + ve }(\%)\end{array}$} \\
\hline & & C/SC (L) & C/SC (R) & C/SC (L) & C/SC (R) & C/SC (L) & C/SC (R) & \\
\hline & & No. + ve & No. + ve & No. + ve & No. + ve & No. + ve & No. + ve & \\
\hline (1) & $\begin{array}{l}\text { Staphylococcus } \\
\text { spp. }\end{array}$ & $13 / 03$ & 02 / 06 & $07 / 03$ & $01 / 05$ & $20 / 06$ & 03 / 11 & $\begin{array}{l}23 / 17 \\
(38.98 / 34.69)\end{array}$ \\
\hline (2) & Escherichia coli & $10 / 01$ & $01 / 04$ & $05 / 02$ & $00 / 05$ & $15 / 03$ & 01 / 09 & $\begin{array}{l}16 / 12 \\
(27.12 / 24.49)\end{array}$ \\
\hline (3) & Bacillus spp. & 00 / 04 & 04 / 02 & $02 / 00$ & $00 / 00$ & 02 / 04 & 04 / 02 & $\begin{array}{l}06 / 06 \\
(10.17 / 12.25)\end{array}$ \\
\hline A. & Single infection & $23 / 08$ & $07 / 12$ & $14 / 05$ & $01 / 10$ & $37 / 13$ & 08 / 22 & $\begin{array}{l}45 / 35 \\
(76.27 / 71.43)\end{array}$ \\
\hline (4) & $\begin{array}{l}\text { Staphylococcus } \\
\text { spp. }+ \text { E. coli }\end{array}$ & 02 / 01 & $00 / 01$ & $03 / 00$ & $00 / 00$ & $05 / 01$ & $00 / 01$ & $\begin{array}{l}05 / 02 \\
(8.48 / 4.08)\end{array}$ \\
\hline (5) & $\begin{array}{l}\text { Staphylococcus } \\
\text { spp. + Bacillus spp. }\end{array}$ & $01 / 02$ & $00 / 01$ & $00 / 00$ & $00 / 00$ & $01 / 02$ & $00 / 01$ & $\begin{array}{l}01 / 03 \\
(1.69 / 6.12)\end{array}$ \\
\hline (6) & $\begin{array}{l}\text { Bacillus spp. }+ \\
\text { E. coli }\end{array}$ & $00 / 02$ & 03 / 01 & $01 / 02$ & $00 / 02$ & $01 / 04$ & $03 / 03$ & $\begin{array}{l}04 / 07 \\
(6.78 / 14.29)\end{array}$ \\
\hline \multirow[t]{2}{*}{ B. } & Mixed infection & $03 / 05$ & 03 / 03 & 04 / 02 & $00 / 02$ & 07 / 07 & $03 / 05$ & $\begin{array}{l}10 / 12 \\
(16.95 / 24.49)\end{array}$ \\
\hline & Total positive & $26 / 13$ & $10 / 15$ & $18 / 07$ & $01 / 12$ & 44 / 20 & $11 / 27$ & $\begin{array}{l}55 / 47 \\
(93.22 / 95.92)\end{array}$ \\
\hline \multirow[t]{2}{*}{ (7) } & Total negative & $03 / 00$ & $00 / 01$ & $00 / 01$ & $01 / 00$ & $03 / 01$ & $01 / 01$ & $\begin{array}{l}04 / 02 \\
(6.78 / 4.08)\end{array}$ \\
\hline & Overall & $29 / 13$ & $10 / 16$ & $18 / 08$ & $02 / 12$ & $47 / 21$ & 12 / 28 & 59 / 49 \\
\hline$=\mathrm{R}$ & $\begin{array}{l}\text { umber of goats } \\
\text { ight halves }\end{array}$ & $\begin{array}{l}\mathrm{I}=\text { Number } \mathrm{c} \\
\mathrm{Q}=\text { Numbel }\end{array}$ & $\begin{array}{l}\text { halves } \\
\text { ff clinical } 1\end{array}$ & lves & $\begin{array}{l}=\text { Clinical } \\
\mathrm{CQ}=\text { Numb }\end{array}$ & $\begin{array}{r}\mathrm{SC}= \\
\text { of sub-clin }\end{array}$ & $\begin{array}{l}\text { Sub-clinical } \\
\text { ical halves }\end{array}$ & $\mathrm{L}=\mathrm{Left}$ ha \\
\hline
\end{tabular}

Bacteriological examination of all the milk samples collected from 108 udder-halves of 54 lactating goats showed 102 (94.44\%) udder-halves had intra-mammary infection (IMI). Of the 59 and 49 udder-halves affected clinically and sub-clinically, of which 55 (93.22\%) and 47 (95.92\%) halves had IMI, respectively (Table 1). It also appears that both the clinical and sub-clinical mastitis affected udder-halves had single (clinical 76.27\% and sub-clinical $71.43 \%$ ) and mixed (clinical $16.95 \%$ and sub-clinical $24.49 \%$ ) bacterial infections (Table 1). No significant difference was recorded on the prevalence of intramammary bacterial infection between the clinically (93.22\%) and sub-clinically (95.92\%) affected udder-halves. The major bacteria identified were Staphylococcus spp. (clinical halves 38.98\% and sub-clinical halves 34.69\%), Escherichia coli (clinical halves 27.12\% and sub- 


\section{H. Sarker and M. A. Samad}

clinical halves $24.49 \%$ ) and Bacillus spp. (clinical halves $10.17 \%$ and sub-clinical halves $12.25 \%$ ) as a single infection, while $16.95 \%$ clinical and $24.49 \%$ sub-clinical halves had mixed infection with these three organisms (Table 1). These bacterial pathogens have been reported from mastitic goat milk samples elsewhere (Egwu et al., 1994; Contreras et al., 1995; Manser, 1986; White and Hinckley, 1999; Ameh and Tari, 2000; Ndegwa et al., 2000) and in bovine mastitis milk samples in Bangladesh (Siddique et al., 1989; Mahbub-E-Elahi et al., 1996; Kader et al., 2002). Staphylococci are the most important and prevalent mastitis causing pathogen globally including Bangladesh. These organisms are contagious pathogens can be transmitted during unhygienic milking procedures (Menzies and Ramanoon, 2001). Most of the clinical and sub-clinical mastitis cases were caused by Staphylococcus spp. (38.98\% and 34.69\%) which supports the earlier inland report of Rahman and Samad (1984) and elsewhere (Anyam and Adekeye, 1995).

This study recorded highest prevalence of Staphylococcus spp in comparison to E. coli and Bacillus spp. in both the clinical and sub-clinical mastitis quarters which supports the reports of Hunter (1984), Manser (1986), Guha et al. (1989), Kalogridou-Vassiliadou (1991), Egwu et al. (1994), Ameh et al. (1993) and Wakwoya et al. (2006). It is recognized that $E$. coli and Bacillus spp are the environmental pathogens and their occurrence could be associated with poor hygienic practices in the environment where goats are kept (Burriel, 1997). The high prevalence of coliforms in association with caprine mastitis was consistent with the reports of Moshi et al. (1998) and Ameh and Tari (2000) who reported 28.5\% and 30\% prevalence of coliforms from dairy goats respectively. The high prevalence of coliform infection in both the clinical and sub-clinical quarter infections recorded in this study could be associated with the unclean environment of goats maintained under rural conditions. However, coliform mastitis have been reported to be a rare occurrence in goats in developed world (Hunter, 1984; Manser, 1986; East et al., 1987; Ryan and Greenwood, 1990; Contreras et al., 1995; Smith and Roguinsky, 1997) as the $E$. coli is an environmental pathogens and keeping a clean environment, milking clean, dry teats and avoiding teat end injuries may reduce prevalence of infection (Smith and Sherman, 1994).

The milk samples of four clinically infected quarters yielded no bacterial growth during culture. This could be either due to early infection that had been overcome by the body's defense or the udder may have been infected with organisms that need special media and thus missed in the ordinary course of bacterial isolation (Wakwoya et al., 2006). Furthermore, there are reports indicating that mastitis causing coliforms in $20 \%$ of the clinical cases become negative in culturing and coliform infections are usually less than 10 days duration and are rapidly destroyed by inflammatory reactions (Quinn et al., 1999).

The results of in vitro antibiotic sensitivity tests of three bacterial isolates to 10 different antibiotics are presented in Table 2. Antibiotic sensitivity results showed moderately to highly sensitivity (2+ to $3+)$ was recorded in all the tested isolates of Staphylococcus spp. to gentamicin, ciprofloxacin, chloramphenicol, enrofloxacin and oxytetracycline, whereas less to moderate sensitivity was obtained with erythromycin (1+ to $2+)$. Ampicillin, amoxycillin, doxycycline and streptomycin were found resistant to less sensitive (- to $1+)$. All the tested $E$. coli isolates were found highly sensitive (3+) to gentamicin and ciprofloxacillin, moderately to highly

Table 2. Results of in vitro antibiotic sensitivity tests of bacterial isolates of milk samples of mastitic goats

\begin{tabular}{|c|c|c|c|c|}
\hline \multirow[t]{2}{*}{$\mathrm{S} / \mathrm{N}$} & \multirow{2}{*}{$\begin{array}{l}\text { Antibiotics } \\
\text { used }\end{array}$} & \multicolumn{3}{|c|}{ Bacterial isolates tested } \\
\hline & & $\begin{array}{l}\text { Staphylococcus spp. } \\
(\mathrm{n}=10)\end{array}$ & $\begin{array}{l}\text { Escherichia coli } \\
\quad(\mathrm{n}=10)\end{array}$ & $\begin{array}{l}\text { Bacillus spp. } \\
\quad(\mathrm{n}=10)\end{array}$ \\
\hline (1) & Gentamicin (GN) & $2+$ to $3+$ & $2+$ to $3+$ & $2+$ to $3+$ \\
\hline (2) & Ciprofloxacin (CIP) & $2+$ to $3+$ & $2+$ to $3+$ & $2+$ to $3+$ \\
\hline (3) & Erythromycin (ERY) & $1+$ to $2+$ & $2+$ to $3+$ & - $\quad$ to $1+$ \\
\hline (4) & Chloramphenicol (C) & $2+$ to $3+$ & $1+$ to $2+$ & - $\quad$ to $1+$ \\
\hline (5) & Ampicillin (AMP) & - $\quad$ to $1+$ & - $\quad$ to $1+$ & - \\
\hline (6) & Amoxycillin (AMX) & - $\quad$ to $1+$ & $1+$ to $2+$ & - \\
\hline (7) & Enrofloxacin (ENR) & $2+$ to $3+$ & $1+$ to $2+$ & $2+$ to $3+$ \\
\hline (8) & Oxytetracycline (OT) & $2+$ to $3+$ & $2+$ to $3+$ & $1+$ to $2+$ \\
\hline (9) & Doxycycline (DOC) & - $\quad$ to $1+$ & $1+$ & $1+$ to $2+$ \\
\hline (10) & Streptomycin (SM) & - $\quad$ to $1+$ & - $\quad$ to $1+$ & - $\quad$ to $1+$ \\
\hline
\end{tabular}

- = Resistance $\quad 1+=$ Less sensitive $\quad 2+=$ Moderately sensitive $\quad 3+=$ Highly sensitive 
sensitive $(2+$ to $3+)$ to erythromycin and oxytetracycline, moderately sensitive $(2+)$ to chloramphenicol and less sensitive $(1+)$ to doxycycline, whereas resistant to less sensitive (- to $1+$ ) results were obtained with ampicillin and streptomycin. Isolates of Baccilus species were found moderately to highly sensitive $(2+$ to $3+)$ to gentamicin, ciprofloxacin and enrofloxacin, less to moderate sensitive (1+ to $2+$ ) to oxytetracycline and doxycycline, less sensitive $(1+)$ to chloramphenicol, resistant to less sensitive (- to $1+$ ) to erythromycin and streptomycin, whereas ampicillin and amoxycillin were fully resistant (-) to these isolates. The results of antibiogram studies with 10 different antibiotics against three different isolates of bacteria could not be compared due to lack of similar inland reports on caprine mastitis. However, these results are in consistent with the reports made elsewhere (Egwu et al., 1994; Bhujbal et al., 1999; Wakwoya et al., 2006). Egwu et al. (1994) reported the drug resistant to bacterial isolates of coliforms, Staphylococcus spp. and Streptococcus spp. isolated from mastitic goats in Nigeria. Bhujbal et al. (1999) reported the susceptibility of mastitis organisms from goats showed resistant to chloramphenicol (12.2\%), gentamicin (21.3\%), oxytetracycline (57.6\%), ampicillin (78.8\%) and amoxycillin (100\%). Wakwoya et al. (2006) reported S. aureus (7.1\%), Bacillus spp. (37.8\%) and E. coli $(40.4 \%)$ resistant to one or more of the antimicrobials tested.

Gentamicin, enrofloxacin and ciprofloxacin and some extent to oxytetracycline are less commonly used for the treatment of mastitis in Bangladesh resulting in higher efficacy of these drugs. Gentamicin and ciprofloxacin proved to be the drug of choice for the treatment of caprine mastitis caused by Staphylococcus spp., E. coli and Bacillus spp. More number of isolates showed resistance to ampicillin, amoxycillin and streptomycin to all these three bacterial pathogens associated with caprine mastitis. Indiscriminate and frequent use of these antibiotics in animals could be the reason for their ineffectiveness against these bacterial pathogens. Since, streptomycin has been extensively used along with penicillin for treating mastitis, it may have led to the development of high resistance in bacteria against this antibiotic.

\section{CONCLUSIONS}

It appears from this study that an overall $5.273 \%$ prevalence of clinical mastitis was recorded in goats maintained under rural condition in Bangladesh and its prevalence was found significantly higher in left udderhalves $(79.66 \%)$ in comparison to the right $(20.34 \%)$ halves. The high prevalence of intra-mammary infection was also recorded in apparently normal udder-halves (95.92\%) of lactating goats those had clinical mastitis in their other quarters. In addition, there was no significant difference on the types of bacterial pathogens between clinically (93.22\%) and sub-clinically (95.92\%) affected quarters. Antibiotic sensitivity patterns showed gentamicin and ciprofloxacin are the possible effective antibiotics against the major prevalent mastitis pathogens. Examination of udder of lactating goats at regular interval should be done to detect the clinical mastitis and those goats will have clinical mastitis in one quarter should be required similar therapeutic management for both the quarters.

\section{ACKNOWLEDGEMENTS}

We thank goat owners of the study area in the districts of Joypurhat and Mymensingh, Bangladesh for their cooperation and support during collection of milk samples and information.

\section{REFERENCES}

1. Ameh JA and Tari IS (2000). Observations on the prevalence of caprine mastitis in relation to predisposing factors in Maiduguri. Small Ruminant Research 35: 1-5.

2. Ameh JA, Addo PB, Adekeye JO and Gyang EO (1993). Prevalence of clinical mastitis and intramammary infections in Nigerian goats. Preventive Veterinary Medicine 17: 41-46.

3. Anyam AA and Adekeye JO (1995). Bacterial flora associated with mastitis in goats and sheep in Zaria (Nigeria) area. Bulletin of Animal Health and Production of Africa 43 : 163-166.

4. Bhujbal J, Deshumukh V, Abdul A, Gujar M and Aziz A (1999). Goat mastitis microflora and antibiogram. Indian Journal of Comparative Microbiology, Immunology and Infectious Diseases 20: 44-46.

5. Boscos C, Stefanakis A, Alexopoulos CB and Samartzi F (1996). Prevalence of sub-clinical mastitis and influence of breed, parity, stage of lactation and mammary bacteriological status on goats. Journal of American Veterinary Medicine 2: 1244-1247. 


\section{H. Sarker and M. A. Samad}

6. Bozhilov B (1970). Aetiology of bacterial mastitis of goats in Khaskova district. Veterinary Medicine. 7: 31-36.

7. Burriel AR (1997). Resistance of coagulase-negative staphylococci isolated from sheep to various antimicrobial agents. Research in Veterinary Science 63: 189-190.

8. Contreras A, Corrales JC, Sierra D and Marcob J (1995). Prevalence and etiology of non-clinical intramammary infection in Murciano-Granadina goats. Small Ruminant Research 17: 71-78.

9. Cowan ST and Steel JK (1974). Manual for the Identification of Medical Bacteria. $1^{\text {st }}$ edn., Cambridge University Press, London.

10. Cruickshank R, Duguid JP, Marmion BP and Swain RHA (1975). Medical Microbiology. Vol. II. $12^{\text {th }}$ edn., Crurchill Livingstone, New York.

11. DaSilva ER, Siqueira AM, Martins JCD, Ferreira WPB and DaSilva N (2004). Identification and in vitro antimicrobial susceptibility of Staphylococcus species isolated from goat mastitis in the Northeast of Brazil. Small Ruminant Research 55: 45-49.

12. East NE, Birnie EP and Farver TB (1987). Risk factors associated with mastitis in dairy goats. American Journal of Veterinary Research 48: 776-779.

13. Egwu GO, Zaria LT, Onyeyili PA, Ambali AG, Adamu SS and Birdling M (1994). Studies on the microbiological flora of caprine mastitis and antibiotic inhibitory concentrations in Nigeria. Small Ruminant Research 14: 233-239.

14. Ellner DP (1978). Current Procedures in Clinical Bacteriology. $1^{\text {st }}$ edn., Charles C. Thomas, Springfield, Illinois, USA.

15. FAO (2007). Production Yearbook 2007. Food and Agriculture Organization of the United Nations. Statistical Series, Rome, Italy.

16. Guha C, Pramanik AK, Misra SK and Benerjee AK (1989). Studies on the incidence and diagnosis of subclinical mastitis in goats and in vitro sensitivity of the isolated pathogens. Indian Veterinary Journal 66: 601-604.

17. Haenlein GFW (2004). Goat milk in human nutrition. Small Ruminant Research 51: 155-163.

18. Hunter AC (1984). Microflora and somatic cell count in goat milk. Veterinary Record 114: 318-320.

19. Jha VC, Thakur PR and Yadav JN (1994). Bacterial species isolated from clinical bovine mastitis and their antibiotic patterns. Veterinary Review Kathmandu 9: 21-23.

20. Kader MA, Samad MA, Saha S and Taleb MA (2002). Prevalence and aetiology of sub-clinical mastitis with antibiotic sensitivity to isolated organisms among milch cows in Bangladesh. Indian Journal of Dairy Science 55: 218-223.

21. Kalogridou-Vassiliadou D (1991). Mastitis related pathogens in goat milk. Small Ruminant Research 4: 203212.

22. Khan AZ and Muhammad G (2005). Quarter-wise comparative prevalence of mastitis in buffaloes and cross-bred cows. Pakistan Veterinary Journal 25: 9-12.

23. Kreig NR and Holt JG (1984). Bergey's Manual of Systematic Bacteriology. Vol. 1, Williams and Wilkins, Baltimore.

24. Mahbub-E-Elahi ATM, Rahman MA, Rahman MM, Rahman MM, Rahman MM and Prodhan MAM (1996). Isolation and identification of bacteria from different quarters of mastitis affected dairy cows in Bangladesh. Bangladesh Veterinary Journal 30: 63-65.

25. Manser PA (1986). Prevalence, causes and laboratory diagnosis of sub-clinical mastitis in the goat. Veterinary Record 17: 552-554.

26. Mbilu TJNK (2007). Status of mastitis in lactating goats at Sokoine University of Agriculture and neighboring smallholder farms in Morogoro Municipality, Tanzania. Livestock Research Rural Development 19: 1-8.

27. Menzies PI and Ramanoon SZ (2001). Mastitis of sheep and goats. Veterinary Clinical North America Food Animal Practice 17: 332-352.

28. Moshi NG, Kitaro GC and Minga UM (1998). Prevalence of mastitis in dairy goats in some selected farms in Morgoro and Arusha, Tanzania. Tanzanian Journal of Agriculture Science 1: 173-180.

29. Ndegwa EN, Mulei CM and Munyan SJM (2000). The prevalence of sub-clinical mastitis in dairy goats in Kenya. Journal of South African Veterinary Association 71: 4-8. 
30. Quinn PJ, Carter ME, Markey B and Carter GR (1999). Clinical Veterinary Microbiology. Mosby Publishing, London. p 327-244.

31. Rahman A (1981). Mastitis in goat and its treatments with leukomycin. Veterinary Medical Review 2: 183185.

32. Rahman MM and Samad MA (1984). A note on the incidence of mastitis in Black Bengal goat. Veterinarian (India) 8: 11.

33. Ryan DP and Greenwood PL (1990). Prevalence of udder bacteria in milk samples from four dairy goat herds. Australian Veterinary Journal 67: 362-364.

34. Samad MA (2008). Animal Husbandry and Veterinary Science. Volume 2, $1^{\text {st }}$ edn., LEP No. 11, BAU Campus, Mymensingh, Bangladesh.

35. Siddique MAB, Rahman BM, Hossain WIMA, Rahman MA and Khan RI (1989). Microorganisms causing mastitis in dairy cattle in Mymensingh and their response to chemotherapeutic agents. Bangladesh Veterinary Journal 23: 119-124.

36. Smith MC and Roguinsky M (1997). Mastitis and other diseases of the goat's udder. Journal of American Veterinary Medical Association 171: 1241-1248.

37. Smith MC and Sherman DM (1994). Mammary gland and milk production. In: Goat Medicine, Lea \& Febiger, Philadelphia, PA, USA. Pp. 474-479.

38. Wakwoya A, Molla B, Belihu K, Kleer J and Hildebrantdt G (2006). A cross-sectional study on the prevalence, antimicrobial susceptibility patterns and associated bacterial pathogens of goat mastitis. International Journal of Applied Research in Veterinary Medicine 4: 169-176.

39. White EC and Hinckley LS (1999). Prevalence of mastitis pathogens in goat milk. Small Ruminant Research 33: $117-121$. 